\title{
Ticks on birds from Cerrado forest patches along the Uberabinha river in the Triângulo Mineiro region of Minas Gerais, Brazil
}

\author{
Carrapatos em aves em matas de cerrado ao longo do rio Uberabinha na região do Triângulo \\ Mineiro de Minas Gerais, Brasil
}

\author{
Khelma Torga ${ }^{I}$ Graziela Tolesano-Pascoli ${ }^{I}$ Jacqueline Bonfim Vasquez ${ }^{\mathrm{I}}$ \\ Eurípedes Luciano da Silva Júnior ${ }^{\mathrm{I}}$ Marcelo Bahia Labruna ${ }^{\mathrm{II}}$ \\ Thiago Fernandes Martins ${ }^{\text {II }}$ Maria Ogrzewalska ${ }^{I I}$ Matias Pablo Juan Szabó ${ }^{*}$
}

\begin{abstract}
We herein describe ticks parasitizing birds in forest fragments along the Uberabinha River, a major watercourse that cuts through patches of remnants of Brazilian savannah in Uberlândia, Minas Gerais, Brazil. Overall 352 birds from 62 species, overwhelmingly, Passeriformes, were captured with mist-nets. The most abundant bird species was Basileuterus hypoleucus $(n=36)$, followed by Lanio penicillata $(n=24)$ and Thalurania furcata $(n=23)$. Thirty one birds, all Passeriformes, were found infested with 56 ticks from which 12 were larvae and 44 nymphs, all from the Amblyomma genus. Highest infestation prevalence was found on Taraba major (66.6\%), Thamnophilus pelzeni (60\%) and Saltator maximus (50\%). The mean intensity of tick infestation was low (1.8 tick per infested bird) with most of the parasites located on the neck (60\%) of birds, followed by the head (20\%). All larvae were attached to the skin around the eyes of birds. Amblyomma nodosum was the most numerous tick species found attached to birds ( $n=23$ nymphs, $52.3 \%$ of nymphs) followed by Amblyomma longirostre ( $n=5,11.4 \%$ of nymphs). Ecological relationships are discussed.
\end{abstract}

Key words: Amblyomma nodosum, Amblyomma longirostre, fragmentation.

\section{RESUMO}

Descrevemos aqui carrapatos que parasitam aves em fragmentos florestais ao longo do rio Uberabinha, o principal curso de água que corta manchas de remanescentes de Cerrado em Uberlândia, Minas Gerais, Brasil. Ao todo, foram capturadas, com redes de neblina, 352 aves, de 62 espécies, em sua maioria, Passeriformes. As espécies de aves mais abundantes foram Basileuterus hypoleucus com 36 indivíduos, seguido de Lanio penicillata $(n=24)$ e Thalurania furcata $(n=23)$. Trinta e uma aves, todas Passeriformes, estavam infestadas com 56 carrapatos, sendo 12 larvas e 44 ninfas, todos do gênero Amblyomma. A prevalência de infestação mais elevada foi encontrada em Taraba major (66,6\%), Thamnophilus pelzeni (60\%) e Saltator maximus
(50\%). A intensidade média de infestação por carrapatos foi baixa ( 1,8 carrapato por ave infestada) e a maior parte dos parasitas recolhidos estava localizada no pescoço (60\%) das aves, seguido pela cabeça (20\%). Todas as larvas estavam fixadas à pele ao redor dos olhos das aves. Amblyomma nodosum foi a espécie de carrapato mais numerosa encontrada nas aves ( $n=23$ ninfas, 52,3\% das ninfas), seguido de Amblyomma longirostre ( $n=5$, $11,4 \%$ das ninfas). Relações ecológicas são discutidas.

Palavras-chave: Amblyomma nodosum, Amblyomma longirostre, fragmentação.

\section{INTRODUCTION}

Information about ticks from birds is scanty in the Neotropical region. Such information paucity can be attributed to, on one side, bird species richness, and on the other side technical difficulties for bird capture as well as lack of appropriate keys for identification of tick immatures in the Neotropical region. In spite of that, in the past few years a few systematic studies have been conducted in Brazil for the identification of bird tick species and related pathogenic microorganisms. Tick identification was improved by molecular methods as well as a key for Amblyomma nymphs of the country (MARTINS et al., 2010). Thus there are recent records of tick species on birds from Araucaria forest (ARZUA \& BARROSBATTESTI, 1999; ARZUA et al., 2003); Atlantic forest (LABRUNA et al., 2007; OGRZEWALSKA et al., 2008, 2009), Amazon (OGRZEWALSKA et al., 2010), Cerrado (TOLESANO-PASCOLI et al.,

\footnotetext{
IUniversidade Federal de Uberlândia (UFU), 38400-902, Uberlândia, MG, Brasil. E-mail: szabo@famev.ufu.br. *Autor para correspondência.

"Faculdade de Medicina Veterinária e Zootecnia, Universidade de São Paulo (USP), São Paulo, SP, Brasil. Received 11.20.12 Approved 04.16.13 Returned by the author 07.19.13 CR-2012-1160.R1
} 
2010; LUZ et al., 2012) and northeastern Brazil (OGRZEWALSKA et al., 2011).

However such efforts are still insufficient for the amount of information needed to understand such host-parasite relationships. These relationships are not devoid of importance; birds may be regarded as hosts with high potential for the dispersal of ticks and tick-borne pathogens. Moreover birds might be important hosts for the maintenance of particular tick species. In fact, birds in the Neotropical region seem to contribute to the life cycle of many tick species by providing blood meal for their immature stages. This is the case of Amblyomma longirostre, a Neotropical tick; whereas rodents of the family Erethizontidae have been recorded as the principal hosts for adults, immature stages feed on birds (Reviewed by NAVA \& GUGLIELMONE., 2010). Furthermore recent observations in Brazil showed that bird ticks may harbor spotted fever group Rickettsia and which are potentially pathogenic to human beings (OGRZEWALSKA et al., 2009).

It is thus of upmost importance to gather information about the main bird-tick relationships, their environment as well as other hosts involved in each tick's life cycle. Such ecological data is the basis for the epidemiology of tick-borne diseases and preventive measures. Basic step to achieve such goal is to describe naturally occurring ticks on birds in the various biomes from the country

Considered one of the 25 hotspots of global biodiversity, the Cerrado (or Brazilian savannah), has about $80 \%$ of its full length already converted into fragments (MYERS et al., 2000), mainly due to agricultural activities (SILVA et al., 2006). Such changes reduce natural areas by increasing human contact with wild animals and consequently with various parasites of the original ecosystems, including ticks (KNIGHT, 1992). However, little is known about the occurrence of ticks on birds existing in this ecosystem. At the same time this biome is known to be very rich in birds summing up as much as 864 species, 36 of which considered endemic (SILVA, 1995; SILVA \& SANTOS, 2005; PINHEIRO \& DORNAS, 2009).

Thus, the aim of this work was to characterize the ticks parasitizing birds in the region of Triângulo Mineiro (MG), more specifically in forest fragments along the Uberabinha river (Uberlândia - MG).

\section{MATERIAL AND METHODS}

Location: The study was conducted in deciduous, semideciduous and gallery forests, in the
Uberlândia municipality (Triângulo Mineiro region), Minas Gerais State, Brazil. Sampled areas $(n=6)$ had from 12.90 to 58.50 ha and were located along the Uberabinha River (1840’50’'S; 48²9’57’'W). This river supplies the city of Uberlandia and is a tributary of the Araguari River. These forestall reserves are surrounded by cattle pastures. The local climate is subtropical with a dry season (May to September) and a rainy season (October to April) (ROSA et al., 1991). Average annual temperatures range from 20 to $25^{\circ} \mathrm{C}$, with annual average humidity of $71 \%$ and average annual rainfall of $1.550 \mathrm{~mm}$.

Bird capture: Birds were captured in five consecutive campaigns (September and December of 2008, and January, March and May of 2009). At each campaign all six areas were sampled for one day (a dawn and a sunset) each, with the aid of 19 mist-nets, each 12 meters long, 2.5m high. Captured birds were identified, weighed, measured and received metallic bands provided by CEMAVE (Centro Nacional de Pesquisa para Conservação de Aves Silvestres, license $n^{\circ}$. 3019/1). Capture of birds was authorized by IBAMA (Instituto Brasileiro do Meio Ambiente e dos Recursos Naturais Renováveis, license $n^{\circ}$ 373/2008 Nufas MG).

Tick collection: Search for ticks was done by blowing systematically the feathers on the whole surface of each bird to expose the skin and attached parasites. Each bird was examined sequentially by two of the authors and typically took from three to six minutes according to bird's size, behavior and number of ticks found. Ticks were collected with tweezers and placed in plastic containers with leaves to prevent desiccation. Birds were released at the same site.

Tick identification: Birds in Brazil are mainly parasitized by Amblyomma immature stages. Unfortunately, there is no reliable key for the identification of Neotropical Amblyomma larvae, and until 2010 a key for Amblyomma nymphs was also lacking. Thus identification was done initially by rearing ticks until the adult stage in the laboratory or by molecular methods as described before (OGRZEWALSKA et al., 2009). Adult ticks and later nymphs were identified under a stereomicroscope, according to morphological criteria and dichotomous keys (ONÓFRIO et al., 2006, MARTINS et al., 2010). Voucher tick specimens collected during this study have been deposited in the FAMEV/UFU Tick Collection, Federal University of Uberlândia (accession numbers: 626-630).

Ciência Rural, v.43, n.10, out, 2013. 


\section{RESULTS}

Overall three hundred fifty-two (352) birds from sixty-two species, overwhelmingly, Passeriformes, were captured. The most abundant bird species was Basileuterus hypoleucus with thirtysix individuals, followed by Lanio penicillata $(n=24)$ and Thalurania furcata $(\mathrm{n}=23)$. Only one individual was captured from eighteen bird species and seventytwo individuals were recaptured during the study.

Thirty-one birds, all Passeriformes, were found infested with 56 ticks (Table 1) from which 12 were larvae and 44 nymphs, all from the Amblyomma genus. Overall infestation prevalence of birds was of $8.8 \%$. Prevalence and mean infestation intensity for each bird species is shown in table 1. Highest infestation prevalence was found on Taraba major (66.6\%), Thamnophilus pelzeni (60\%), and Saltator maximus (50\%), however only three, five and four individuals of theses bird species were captured, respectively.

The mean intensity of tick infestation was low (1.8 tick per infested bird) and most of the parasites collected were on the neck (60\%) of birds, followed by the head (20\%) and nape (20\%). All larvae were attached to the skin around the eyes of birds. No adult tick was found on these hosts.

Amblyomma nodosum was the most numerous tick species found attached to birds $(n=23$ nymphs, 52.3\% of nymphs) followed by Amblyomma longirostre ( $\mathrm{n}=5,11.4 \%$ of nymphs). Ticks that could not be identified to species levels were retained as Amblyomma spp.

No tick was found on 47 bird species ( $\mathrm{n}=155$ birds). These species, families and number of captured individuals are as follows: Leptotila verreauxi ( $\mathrm{n}=4$; Columbidae); Glaucidium brasilianum ( $\mathrm{n}=1 ; \quad$ Strigidae); Antrostomus rufus ( $\mathrm{n}=1$; Caprimulgidae); Phaetornis pretrei ( $\mathrm{n}=16)$; Chlorostilbon lucidus $(\mathrm{n}=1)$; Thalurania furcata $(\mathrm{n}=23) ;$ Amazilia fimbriata $(\mathrm{n}=1$; Trochilidae); Baryphtengus ruficapillus ( $\mathrm{n}=5)$; Momotus momota ( $\mathrm{n}=4)$; (Momotidae); Galbula ruficauda ( $\mathrm{n}=2$; Galbulidae); Nonnula rubecula $(\mathrm{n}=1)$; Monasa nigrifrons $(\mathrm{n}=1)$ (Bucconidae); Pteroglossus castanotis ( $\mathrm{n}=4$; Ramphastidae); Picumnus albosquamatus $(\mathrm{n}=1)$; Veniliornis passerinus $(\mathrm{n}=1)$; Colaptes melanochloros $(\mathrm{n}=1)$; Campephilus melanoleucus $(\mathrm{n}=1) \quad$ (Picidae); Dysithamnus mentalis ( $\mathrm{n}=2 ;$ Thamnophilidae); Sittasomus griseicapillus $(\mathrm{n}=1)$; Dendrocolaptes platyrostris $(\mathrm{n}=3)$; Lepidocolaptes angustirostris $(\mathrm{n}=1) \quad$ (Dendrocolaptidae); Synallaxis scutata $(\mathrm{n}=2)$; Hylocryptus rectirostris $(\mathrm{n}=4)$ (Furnariidae); Corythopis delalandi ( $\mathrm{n}=2 ; \quad$ Rynchocyclidae); Elaenia spectabilis $(\mathrm{n}=1)$; Camptostoma obsoletum $(\mathrm{n}=1)$; Lathrotriccus euleri $(\mathrm{n}=1)$; Cnemotriccus fuscatus ( $\mathrm{n}=4)$; Myiozetetes similis $(\mathrm{n}=1)$; Casiornis rufus $(\mathrm{n}=1)$; Myiarchus ferox $(\mathrm{n}=1)$ (Tyrannidae); Neopelmapallescens $(\mathrm{n}=9)$; Piprafasciicauda $(\mathrm{n}=22)$ (Pipridae); Pachyramphus validus ( $\mathrm{n}=1$; Tityridae); Cyclarhis gujanensis $(\mathrm{n}=2)$; Vireo olivaceus $(\mathrm{n}=1)$ (Vireonidae); Pheugopedius genibarbis $(\mathrm{n}=3)$; Cantorchilus leucotis $(\mathrm{n}=1)$ (Troglodytidae); Turdus rufiventris ( $\mathrm{n}=3)$; Turdus amaurochalinus $(\mathrm{n}=2)$; Turdus subalaris ( $\mathrm{n}=1)$ (Turdidae); Tachyphonus rufus $(\mathrm{n}=1)$; Tangara sayaca $(\mathrm{n}=1)$; Tangara cayana $(\mathrm{n}=2)$; Dacnis cayana $(\mathrm{n}=1)$ (Thraupidae); Volatinia jacarina (n=11; Emberizidae); Cyanoloxia brissonii ( $\mathrm{n}=1$; Cardinalidae).

\section{DISCUSSION}

Adult ticks were not found on birds captured in this work. Lack of adult tick stage on birds in Brazil is a common feature (LABRUNA et al., 2007; OGRZEWALSKA et al., 2008) and highlights the importance of birds as hosts for immature stages (larvae and nymphs) of these ectoparasites, at least for ticks from the Amblyomma genus.

Overall tick infestation prevalence from this survey was low. Previous studies in the Brazilian savannah (Cerrado) found ticks on 24\% (MARINI \& COUTO, 1997), 28\% (KANEGAE, 2003), 52\% (TOLESANO-PASCOLI et al., 2010) and 17\% (LUZ et al., 2012). Reasons for this low prevalence are at the moment speculative. One possibility is that this particular area had lower environmental infestation at tick questing sites for birds. Since most of the bird and tick sampling from this work was done during spring and summer, seasonal influences also might have had a role in the low infestation prevalence. Anyhow these are important topics to be explored in future research.

Location of ticks predominantly on the head, with nymphs on the neck and larvae around the eyes have been observed before (OGRZEWALSKA et al., 2008; OGRZEWALSKA, 2009; TOLESANOPASCOLI et al., 2010) and indicates parasitism site preferences of ticks. It is possible to suppose that these sites are those that protect tick from host selfgrooming enhancing survival chance of the parasite.

Uneven number of the various bird species captured and seasonal restriction of sampling precludes a clear-cut analysis of tick species association with bird species or at least bird 
Table 1 - Prevalence and mean intensity, ticks species and larva $(\mathrm{L})$ an nymph $(\mathrm{N})$ numbers and of infestation on passerine birds in a semideciduous forest patch of the Brazilian cerrado in the municipality of Uberlândia, State of Minas Gerais, Southeastern Brazil, 2008-2009.

\begin{tabular}{|c|c|c|c|c|c|c|}
\hline \multirow{3}{*}{$\begin{array}{l}\text { Bird family/ Species } \\
\text { Thamnophilidae }\end{array}$} & \multirow[t]{2}{*}{ No. infested/ No. captured } & \multirow[t]{2}{*}{ Preval. (\%) } & \multirow[t]{2}{*}{ Mean Intensit. } & \multirow[t]{2}{*}{ Species } & \multicolumn{2}{|c|}{ Tick $n^{\circ}$} \\
\hline & & & & & $\mathrm{L}$ & $\mathrm{N}$ \\
\hline & & & & & & \\
\hline \multirow[t]{2}{*}{ Taraba major } & $02 / 03$ & 66.6 & 4,5 & A. nodosum & & 4 \\
\hline & & & & Amblyomma sp. & & 5 \\
\hline \multirow{2}{*}{ Thamnophilus pelzeni } & 03/05 & 60 & 1,3 & A. nodosum & & 1 \\
\hline & & & & Amblyomma sp. & & 3 \\
\hline \multicolumn{7}{|l|}{ Tyrannidae } \\
\hline \multirow{3}{*}{ Leptopogon amaurocephalus } & $02 / 24$ & 8.3 & 1,5 & Amblyomma sp. & & 1 \\
\hline & & & & A. longirostre & & 1 \\
\hline & & & & A. nodosum & & 1 \\
\hline Myiarchus tyrannulus & $01 / 04$ & 25 & 1 & A. nodosum & & 1 \\
\hline \multirow{2}{*}{ Tolmomyias sulphurescens } & 03/09 & 33.3 & 1 & A. nodosum & & 1 \\
\hline & & & & Amblyomma sp. & & 2 \\
\hline \multicolumn{7}{|l|}{ Pipridae } \\
\hline Antilophia galeata & $01 / 15$ & 6.7 & 6 & Amblyomma sp. & 6 & \\
\hline \multicolumn{7}{|l|}{ Turdidae } \\
\hline \multirow{2}{*}{ Turdus leucomelas } & $04 / 29$ & 13.8 & 1 & A. nodosum & & 3 \\
\hline & & & & Amblyomma sp. & 1 & \\
\hline \multicolumn{7}{|l|}{ Thraupidae } \\
\hline \multirow[t]{3}{*}{ Saltator maximus } & $02 / 04$ & 50 & 3 & Amblyomma sp. & & 2 \\
\hline & & & & A. nodosum & & 3 \\
\hline & & & & A. longirostre & & 1 \\
\hline Saltator similis & $01 / 04$ & 25 & 1 & A. nodosum & & 1 \\
\hline Lanio penicillata & $02 / 28$ & 7.2 & 1,5 & Amblyomma sp. & 3 & \\
\hline \multirow[t]{2}{*}{ Lanio cucullatus } & $01 / 04$ & 25 & 2 & A. nodosum & & 1 \\
\hline & & & & Amblyomma sp. & & 1 \\
\hline \multicolumn{7}{|l|}{ Emberizidae } \\
\hline Arremon flavirostris & $01 / 04$ & 25 & 2 & A. nodosum & & 2 \\
\hline \multicolumn{7}{|l|}{ Parulidae } \\
\hline Basileuterus flaveolus & $01 / 26$ & 3.8 & 1 & A. nodosum & & 1 \\
\hline \multirow{2}{*}{ Basileuterus hypoleucus } & $05 / 51$ & 9.8 & 1 & Amblyomma sp. & 1 & 2 \\
\hline & & & & A. longirostre & & 2 \\
\hline \multicolumn{7}{|l|}{ Icteridae } \\
\hline \multirow{3}{*}{ Cacicus haemorrhous } & $02 / 07$ & 28.6 & 3,0 & Amblyomma sp & 1 & \\
\hline & & & & A. nodosum & & 4 \\
\hline & & & & A. longirostre & & 1 \\
\hline
\end{tabular}

behavior. Moreover tick infested-bird species were not homogeneous regarding their living habits and foraging guild (WILLIS, 1979; MOTTA-JUNIOR,
1990); both arboreal birds, that rarely descend to the ground (eg, A. galeata) and bird species that forage close to or on the ground (B. flaveolus and $\boldsymbol{T}$. 
leucomelas), were tick infested. Thus tick infestation of bird may have occurred on the ground or higher on bushes and trees. Thus host questing location of various tick species that parasitize birds shall be determined by forthcoming research.

Due to the difficulty of identifying immature and losses in the handling of specimens, only 23 ticks were identified: $\boldsymbol{A}$. nodosum $(\mathrm{n}=23)$ and $\boldsymbol{A}$. longirostre $(\mathrm{n}=5)$. The first, known to have the definitive host species of anteater (Myrmecophaga tridactyla and Tamandua tetradactyla), and occasionally armadillos (Euphractus sexcinctus) (BECHARA et al., 2002; MARTINS et al., 2004) that are commonly found in mammals of study region (obs. pers.) and the second, popularly known as "bird earrings”(GUIMARÃES et al. 2001; LABRUNA et al., 2007), found in adult parasite of the porcupines (Coendou spp) and possibly primates. Only two bird species were parasitized by this tick species: $\boldsymbol{S}$. maximus and $\boldsymbol{B}$. hypoleucus. These results indicate a quite complex life cycle for these tick species which involve a mammal host (some of which are arboreal) and Passerine birds. These observations are not devoid of importance if one considers that the tick A. nodosum may be involved in the epidemiology of human rickettsioses. A spotted-fever group Rickettsia closely related to Rickettsia parkeri, was isolated from A. nodosum ticks of Passeriforme birds captured in the Atlantic forest (OGRZEWALSKA et al., 2009).

Our results are preliminary, but still they underscore the importance of wild birds as hosts for immature ixodid ticks and also provide basic information on the host-parasite relationship in the Brazilian savannah domain.

\section{ACKNOWLEDGEMENTS}

This research was supported by Fundação de Amparo à Pesquisa do Estado de Minas Gerais (FAPEMIG) Federal University of Uberlândia, and Conselho Nacional de Desenvolvimento Científico e Tecnológico (CNPq) (Academic Career Research Fellowship to M.B.L. and M.P.J.S.). The authors are indebted to CEMAVE/ICMBIO (Centro Nacional de Pesquisa para Conservação de Aves Silvestres) and AGETEL for permissions and logistic support.

\section{REFERENCES}

ARZUA, M.; BARROS-BATTESTI, D.M. Parasitism of Ixodes (multidentatus) auritulus Neumann (Acari: Ixodidae) on Birds from the City of Curitiba, State of Paraná, Southern Brazil. Memórias do Instituto Oswaldo Cruz, v.94, n.5, p.597-603, 1999.

ARZUA, M. et al. Amblyomma aureolatum and Ixodes auritulus (Acari: Ixodidae) on birds in southern Brazil, with notes on their ecology. Experimental and Applied Acarology, v.31, p.283-296, 2003. Available from: <http://dx.doi.org/10.1023/ B:APPA.0000010381.24903.1c>. Accessed: Jan. 05, 2013.

BECHARA, G.H. et al. Ticks associated with armadillo (Euphractus sexcinctus) and anteater (Myrmecophaga tridactyla) of Emas National Park, State of Goias, Brazil. Annual NY Academic. Science, v.969, p.290-293, 2002.

GUIMARÃES, J.H. et al. (Ed.). Ectoparasitos de importância veterinária. São Paulo: Plêidade, 2001. 213p.

KANEGAE, M.F. Comparação dos padrões de ectoparasitismo em aves de Cerrado e de Mata de Galeria do Distrito Federal. 2003. 83f. Dissertação (Mestrado em Ecologia - Universidade de Brasília, DF.

KNIGHT, J.C. Observations on potential tick vectors of human disease in the Cerrado region of Central Brazil. Revista da Sociedade Brasileira de Medicina Tropical, v.25, p.45-146, 1992.

LABRUNA, M.B. et al. Ticks collected form birds in the state of São Paulo, Brazil. Experimental and Applied Acarology, v.43, p.147-160, 2007. Available from: <http://dx.doi.org/10.1007/ s10493-007-9106-x>. Accessed: April 10, 2013.

LABRUNA, M.B. et al. Notes on population dynamics of Amblyomma ticks (Acari: Ixodidae) in Brazil. Journal of Parasitology, v.95 n.4, p.1016-1018, 2009. Available from: <http:// dx.doi.org/10.1645/GE-1878.1>. Accessed: April 15, 2013.

LUZ, H.R. et al. Bird ticks in an area of the Cerrado of Minas Gerais State, southeast Brazil. Experimental and Applied Acarology, v.58 n.1, p.89-99, 2012. Available from: <http:// dx.doi.org 10.1007/s10493-012-9572-7>. Accessed:Feb. 20, 2013.

MARINI, M.A.; COUTO, D. Correlações ecológicas entre ectoparasitas e aves de florestas de Minas Gerais. In: LEITE, L.L.; SAITO, C.H. (Eds). Contribuição ao conhecimento Ecológico do Cerrado. Trabalhos selecionados do $3^{\circ}$ Congresso de Ecologia do Brasil. Brasília: Dept ${ }^{\circ}$ de Ecologia, Universidade de Brasília, 1997. p. $210-218$.

MARTINS, J.R. et al. Occurrence of ticks on giant anteate (Myrmecophaga tridactyla) and collared anteater (Tamandua tetradactyla) in the Pantanal region of Mato Grosso do Sul State, Brazil. Ciência Rural, v.34 n.1, p.293-295, 2004.

MARTINS, T.F. et al. Nymphs of the genus Amblyomma (Acari: Ixodidae) of Brazil: descriptions, redescriptions, and identification key. Ticks and Tick-borne Diseases, v.1,n.2, p.75-99, 2010. Available from: <http://dx.doi.org/10.1016/j.ttbdis.2010.03.002>. Accessed: Feb 05, 2011.

MOTTA-JUNIOR, J.C. Estrutura trófica e composição das avifaunas de três hábitats terrestres na região central do estado de São Paulo. Ararajuba, v.1, p.65-71, 1990.

MYERS, N. et al. Biodiversity hotspots for conservation priorities. Nature, v.403, p.853-858, 2000. Available from: <http://dx.doi. org/10.1038/35002501>. Accessed: Jan. 15, 2012.

NAVA, S.; GUGLIELMONE, A.A. First record of Amblyomma longirostre (Koch, 1844) Acari: Ixodidae) from Peru, with review of this tick's host relationships. Systematic and Applied Acarology, v.15, p.21-30, 2010.

Ciência Rural, v.43, n.10, out, 2013. 
OGRZEWALSKA, M. et al. Ticks (Acari: Ixodidae) infesting wild birds in an Atlantic Forest area in the state of São Paulo, Brazil, with isolation of rickettsia from the tick Amblyomma longirostre. Journal of Medical Entomology, v.45 n.4, p.770-774, 2008. Available from: <http://dx.doi.org/10.1007/s10393-011-0726-6>. Accessed: Feb 15, 2012.

OGRZEWALSKA, M. Efeito da fragmentação florestal na infestação por carrapatos (Acari: Ixodidae) em aves e infeç̧ão de carrapatos por Rickettsia spp no Pontal do Paranapanema, SP. 2009. 105f. Tese (Doutorado em Epidemiologia Experimental e Aplicada às Zoonoses) - Faculdade de Medicina Veterinária e Zootecnia da Universidade São Paulo, SP.

OGRZEWALSKA, M. et al. Rickettsial infection in Amblyomma nodosum ticks (Acari: Ixodidae) from Brazil. Annals of Tropical Medicine and Parasitology, v.103, n.5, p.413-425, 2009. Available from: <http://dx.doi.org/10.1179/136485909X451744>. Accessed: Feb l 15, 2012.

OGRZEWALSKA, M. et al. Ticks (Acari: Ixodidae) infesting wild birds in the eastern Amazon, northern Brazil, with notes on rickettsial infection in ticks. Parasitology Research, v.106, n.4, p.809-816, 2010. Available from: <http://dx.doi.org/10.1007/ s00436-010-1733-1>. Accessed: Jan. 15, 2013.

OGRZEWALSKA, M. et al. Ticks (Acari: Ixodidae) infesting wild birds in the Atlantic Forest in northeastern Brazil, with notes on rickettsial infection in ticks. Parasitology Research, v.108, p.665-670, 2011. Available from: <http://dx.doi.org/10.1007/ s00436-010-2111-8>. Accessed: Jan. 20, 2013.

ONÓFRIO, V.C. et al. Comentários e chaves para as espécies de Amblyomma. In: BARROS-BATTESTI, D.M. et al. Carrapatos de importância médico-veterinária da região neotropical: um guia ilustrado para identificação de espécies. São Paulo: Vox / ICTTD-3/ Butantan, 2006. Cap.6, p.53-71.

PINHEIRO, R.T.; DORNAS, T. Distribuição e conservação das aves na região do Cantão, Tocantins: Ecótono Amazônia/cerrado. Biota Neotropica, v.9, n.1, p.187-205, 2009. Available form: $<$ http://www.biotaneotropica.org.br/v9n1/pt/abstract?inventory+ bn02609012009>. Accessed: Feb. 10, 2012.

ROSA, R. et al. Abordagem preliminar das condições climáticas de Uberlândia (MG). Sociedade e Natureza, v.3, p.91-108, 1991.

SILVA, J.F. et al. Spatial heterogeneity, land use and conservation in the Cerrado region of Brazil. Journal of Biogeography, v.33, n.3, p.536-548, 2006. Available from: <http://dx.doi.org/10.1111 /j.1365-2699.2005.01422.x>. Accessed: Feb. 15, 2012.

SILVA, J.M.C. Birds of the Cerrado region, South America. Steenstrupia, v.21, p.69-92, 1995.

SILVA, J.M.C.; SANTOS, M.P.D. A importância relativa dos processos biogeográficos na formação da avifauna do Cerrado e de outros biomas brasileiros. In: SCARIOT, A. et al. (Eds.). Cerrado: ecologia, biodiversidade e conservação. Brasília: Ministério do Meio Ambiente, 2005. p.223-230.

TOLESANO-PASCOLI, G.V. et al. Ticks on birds in a forest fragment of Brazilian cerrado (savanna) in the municipality of Uberlândia, State of Minas Gerais, Brazil. Revista Brasileira de Parasitologia Veterinária, v.19, n.4, p.244-248, 2010. Available from: <http:// dx.doi.org/10.1590/S1984-29612010000400010>. Accessed: Feb. 20, 2012

WILLIS, E.O. The composition of avian communities in remanescent woodlots in southern. Brazil. Papéis Avulsos de Zoologia, v.33, p.1-25, 1979. 